\title{
The Effect of Using Communicative Language Teaching on Speaking Ability
}

\author{
Rahayu Nindya Ratih \& Hanafi \\ Universitas Muhammadiyah Jember \\ (hanafi@unmuhjember.ac.id)
}

\begin{abstract}
This research aims at investigating the impact of Communicative Language Teaching method on the improvement of students' speaking ability. This is experimental research with non-randomized control group pretest posttest design. Class VII/A is the experimental research group, while class VII/B is the control group. Each of them consists of 22 students. Subjective test is used to collect the data about the students' speaking ability in which the content is based on the curriculum used in the school. The data analysis used is t-test using SPSS version 16. The result of data analysis shows that $\mathrm{p}$ value is 0.016 . The score is lower than 0.05 . Seeing the result we can say that the null hypothesis (Ho) saying that there is no effect of using Communicative Language Teaching on speaking ability is rejected. It means that there is effect of using Communicative Language Teaching on the students' speaking ability.
\end{abstract}

Keywords: Communicative Language Teaching method, speaking ability.

Mastering English for the students is very important since the skill can be the key to study other knowledge. But sometimes the teacher finds difficulties in transferring the skill since there are many aspects involved. One of the difficulties is related to mastering speaking skills, since English is not a daily life language, even it is in formal schools.

Preliminary study conducted by the researcher related to speaking ability was as follows. First, the students are often inhibited about trying to say something in foreign language in the classroom, sometimes they worried about making mistakes or simply shy of the attention that their speech is attracted. It will make them loose of their confidence. Second, students are usually having nothing to say because they cannot think of anything to say. Third, students are easier to speak using their mother tongue rather than English. It is because English is not generally used in their daily life.
The condition gives the writer challenge to look for ways or method to overcome the problem. Seeing the condition, it can simply be said the main problem is about communication. Related to the matter, theoretically, the most suitable approach to use is communicative approach.

The communicative approach in language teaching starts from a theory of language as communication. The goal of language teaching is to develop what Hymes (in Richard, 2001, p. 159) referred to as 'communicative competence'. It was definition of what a speaker needs to know in order to be communicatively competent in a speech community. Communicative Language Teaching is one of the methods which suites with the goal of language teaching especially in teaching speaking. According to Hammer (2002, p. 84), Communicative Language Teaching (CLT) is the name which was given 
to a set of beliefs which included not only about what aspects of language to teach, but also a shift in emphasis in how to teach.

The activities in CLT typically involve students in real or realistic communication, where the accuracy of language they use is less important than successful achievement of the communicative task they are performing. Students should have a desire to communicate something. They should focuses on the content of what they are saying rather than on a particular language form. It means that CLT has an aim at improving students' ability to communicate in oral. That statement is supported by $\mathrm{Wu}$ (2008, p. 50), he stated that CLT emphasizes the speaking skill in order to improve their communicative ability by focusing on meaning, and refuses error correction for maintaining the conversation.

There are some techniques that can be used by the teacher in teaching speaking by using CLT. According to Applebaum (2007, p. 68), there are some examples of communicative activities that can be used by the teacher to teach speaking such as role play, language games, and scramble sentences. On the other hand, Banciu (2012, p. 97) stated that there are some classroom activities that frequently used in CLT such as role play, interviews, information gap, games, language exchanges, surveys and pair work. That statements were supported by Richard (2001, p. 169) who stated that a variety of games and role plays have been prepared to support CLT classes.

In this research, the researcher focused on the implementation of role play as technique in teaching speaking by using CLT in order to know the effect of it. Role plays are very important in CLT because they give students an opportunity to practice communicating in different social contexts and in different social roles (Larsen and Freeman, 2000, p. 134). On the other hand, Harmer (2002, p. 92) stated that role play activities are those where the students are asked to imagine that they are in different students and act accordingly. He gives the example of role play that is the students act a real-life encounter (such as a business meeting, an encounter in an airplane cabin, or an interview) as if they were doing in the real life. Applebaum (2007, p. 269) also stated an example of role play is one student will play as the waiter or waitress and the others will be the customer in the restaurant. In other hand, Brown (2003, p. 174) stated other example of role play is the student will pretend as a tourist asking for direction or pretend as a customer who wants to buy a necklace with lower price in a market.

It may be concluded that role play let the students to act in different context and role where the role they play is taken from their real life. It makes them easier to do the role play because it happened in their daily life. They need to act, to interpret, express and negotiate meaning in a new language. Anyway it can be said that role play let the students to act in different context and role where the role they play is taken from their real life. It makes them easier to do the role play because it happened in their daily life. They need to act, to interpret, express and negotiate meaning in a new language.

According to Shaftel (1982, p. 57), there are eight steps in role playing. The steps and explanations are as follow: 1) 'Warming Up' the Group (Problem Confrontation): This first step of role play presents a problem for the group where they need to learn ways dealing with the problem. This step are consists of two parts. The first part is the teacher and the students decide a problem that should be discussed in role playing. In the second part, the teacher will explain the problem clearly, so the students will understand it well. 2) Selecting Participants for Role Playing: In selecting participants, the teacher asks the students to describe the character in the topic (problem) that has been selected. Students who can explain the character in certain will be chosen to play the character. 3) Setting the Stage: In this step, the role player prepares plan in briefly about what they are going to do. They do not permitted to bring any dialogue, so the action will take naturally by exploring their idea in the action. 4) Preparing the Audience 
to be Participating Observer: In this section, listening skill is needed to make the observing group easier understand the idea of role player. By understanding the role player, they may give other alternatives to help the role player solve the problem. 5) Role Playing (the Enactment): In this section, the role player should live the situation, respond to another's speech and action as they feel the people in those roles would behave. Players must think and feel by themselves, spontaneously reacting to the developing situation. 6) Discussion and Evaluation: This part is one of the most vital steps of role playing. The researcher indicated that the actual taking of roles may have the greatest influence on attitudinal changes; it is in the give-and-take of discussion that problem-solving procedures are refined and learned. The observers are in position to see more consequences to proposals more easily and to see more alternatives problem solving. 7) The Reenactment (Further Role Playing and Discussion): The role player may play their roles over and over again, changing their interpretations and solution. It also may for the new actor to take over the role to demonstrate other interpretations and solutions. 8) Sharing Experience and Generalizing: After a number of alternatives and their consequences have been enacted and discussed, the teacher may ask "has something like this ever happened to someone you know?" These sharing experiences, this exploration of consequences of behavior, achieve several important objectives such as it helps anxious young people to discover that their problem are shared by other people, provides opportunity for the teacher through his supportive leadership, to gain the confidence of the group.

The aspect that is intended to improve in this research is speaking ability. Brown (2003, p. 140) stated that speaking is a productive skill that can be directly and empirically observed by the accuracy and effectiveness of test-takers listening skill, which necessarily compromises the reliability and validity of oral production test. On other hand, Thornbury
(2005, p. 1) stated that "speaking is the ability to speak fluently followed naturally from the teaching of grammar and vocabulary, with bit pronunciation thrown in, and involves both a command of certain skills and several types of knowledge". From the statements, it may be concluded that speaking is the ability to speak fluently by using the target language in order to interact or communicate with others.

The aspects of speaking to be improver are: 1) Fluency meaning the capability of someone to speak in normal speed with few pauses then to continue to speak. Not only about pausing, but also about how to express their idea. It is necessary for the students not to make so many pauses and repetition when they speak. 2) Vocabulary meaning knowledge about vocabulary is needed by the students to understand a sentence. 3) Pronunciation meaning the articulation of word such as volume, stress, pausing, etc. The students should know well how to pronounce a word. It uses to make the conversation easier to understand and 4) Grammar. Grammar in spoken is different from grammar in writing. Students may say a sentence not in correct form in spoken, but the knowledge of grammar is still needed by the students to make sentences.

Related to the use of CLT to improve students' speaking skill, there is no doubt that it logically does. This statement is supported by Wu (2008, p. 28). He stated that CLT emphases the speaking skill in order to improve their communicative ability by focusing on meaning, and refuse error correction for maintaining the conversation. CLT focus on real oral communication where the student is the centered. In classes' activity, the teacher let the students act as negotiator for each other and express their idea by letting them say what they want to say. The teacher himself acts as a facilitator and advisor to help the students by giving feedback to each student.

There is any previous study that can prove that CLT has significance effect in improving students speaking ability. Safitri (2015, p. 14) stated that "there is an 
effectiveness of using CLT in learning speaking to the students of SMPN 1 Semen Kediri." The students' mean score of post-test is higher than the mean score of pre-test. So, it can be said that the students' speaking score is increasing after they are taught using CLT.

Based on the information and the study related to the topic, the researcher determines to investigate the effect of using Communicative Language Teaching method on the students' speaking ability.

\section{Method}

In this research, the researcher uses experimental research. It is to investigate whether there is or there is no significant effect of using Communicative Language Teaching Method on the seventh grade students' speaking ability. An experiment is a scientific investigation in which the researcher manipulates one or more independent variables, controls any other relevant variables, and observes the effect of the manipulations on the dependent variable(s) (Ary, 2010, p. 265). In short, we can say that it is the way to look for the causal relationship between two variables namely Communicative Language Teaching Method and students' speaking ability.

The research is implemented on all of the seventh grade students. The location of the research is SMPN 2 Yosowilangun Lumajang, Indonesia. It consists of seven classes with 172 students, start from VII/A to VII/G. The writer chooses two classes, namely VII/A and $\mathrm{VII} / \mathrm{B}$ as the research samples.

The research design is non-randomized control group, pretest-posttest design. The treatment given is the implementation of Communicative Language Teaching method to improve the students' speaking ability. The subjects' score mentioned here is the learning outcomes of students' speaking before the treatment is given (pre-test) and after the treatment is given (post-test). The procedure of research are as follow; The procedures of the research are as follows; a) determining sample of the research by using purposive sampling, b) determining the experimental group and the control group by flipping a coin, c) giving pretest (Y1) to both experimental and control group, d) counting the mean from each group, e) giving treatment $(\mathrm{X})$ to the experimental group only, f) giving posttest (Y2) to both experimental and control group to know the influence of the treatment that is used, g) counting the mean from each group, and $h$ ) analyzing the result of posttest (Y2) from both experimental and control group using $t$ test on SPSS version 16.

From the process, the researcher got two kinds of data namely data on learning outcome of speaking aspect from experimental class and from control class. The data analysis was done in 4 steps including (1) sorting the data collected taken during teaching learning process (2) presenting the data (3) calculating the degree of influence with the SPSS for Windows ver. 16 using a non-parametric statistical tests were similar to independent sample t-test, and (4) drawing conclusions based on the results of all the data and analysis obtained.

\section{Result and Discussion}

In this research, both of the experimental and control group were given pretest and posttest. The treatment was given to experimental group only by using Communicative Language Teaching Method and the control group was teaching conventionally. The aim of this treatment was to find out the effect of using Communicative Language Teaching Method on students speaking ability. The data analysis was calculated by using SPSS version 16 . The result of the calculation can be seen bellow:

The result of the research can be seen clearly as follow: 
Table 1. Speaking Score of Experimental and Control Group

\begin{tabular}{ccc}
\hline Aspect & Experimental Group & Control Group \\
\hline Higher score of pretest & 75 & 75 \\
\hline Lower score of pretest & 65 & 60 \\
\hline Higher score of posttest & 85 & 80 \\
\hline Lower score of posttest & 70 & 60 \\
\hline Mean score pretest & 69.32 & 70.45 \\
\hline Mean score posttest & 75.23 & 71.82 \\
\hline Number of students & 22 & 22 \\
\hline
\end{tabular}

Based on the result, the experimental and posttest was 75.23. The different mean group had mean score of pretest was 69.32 was 5.91. In the other hand, control group had
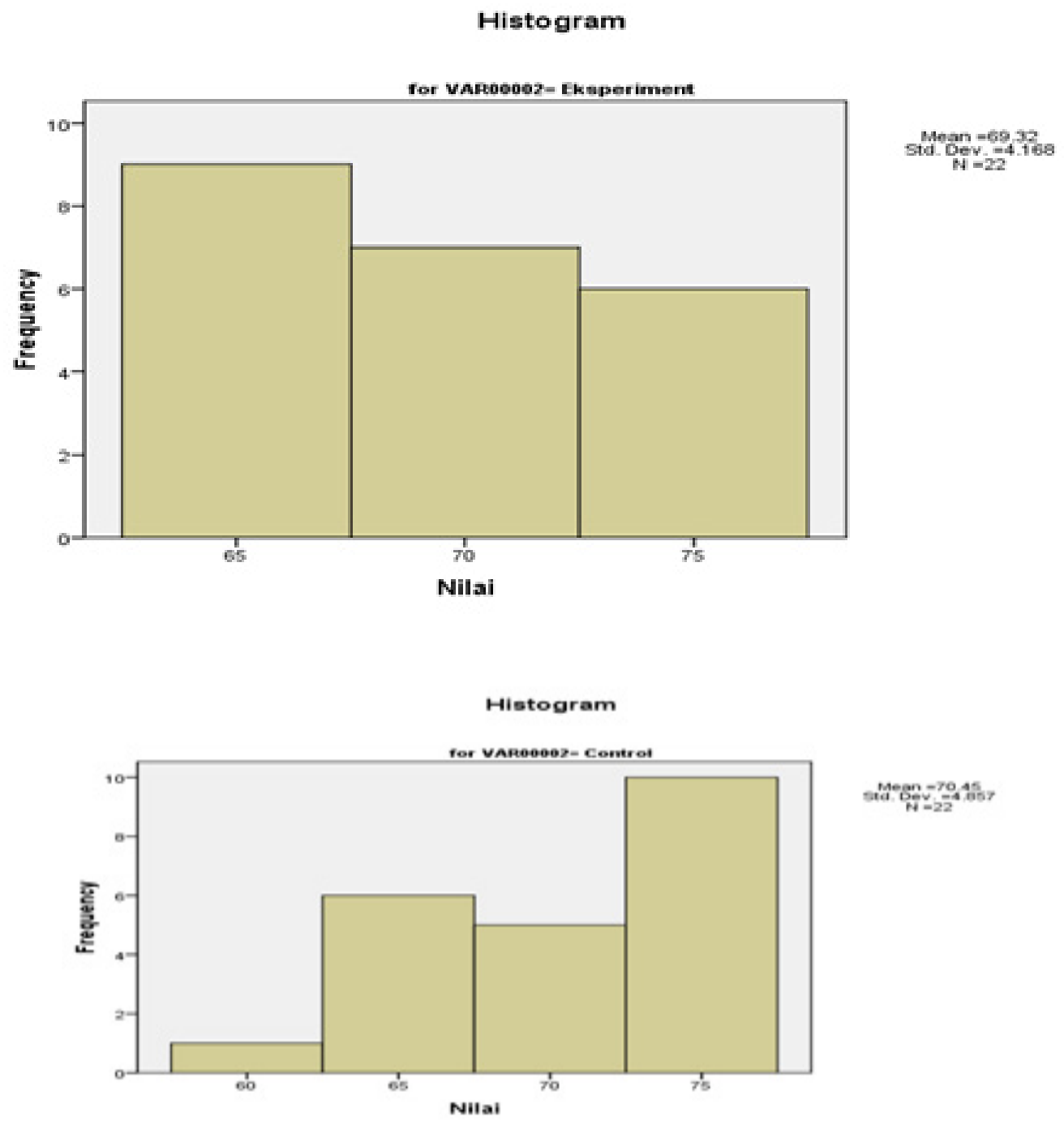

Diagram 1. The Pretest Score of Experimental and Control Group 

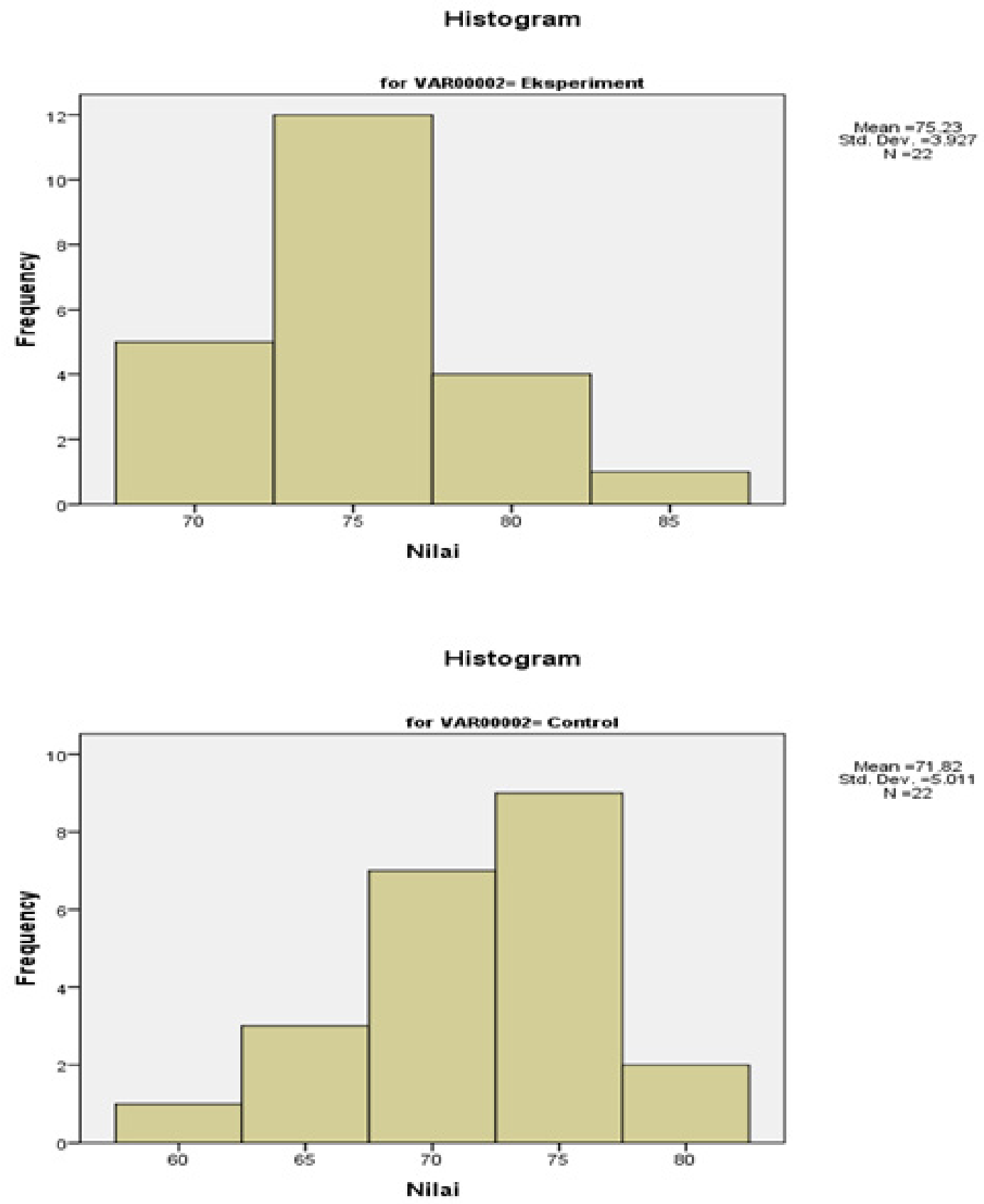

Diagram 2 the Posttest Score of Experimental and Control Group

mean score of pretest was 70.45 and posttest was 71.82 . The different mean was 1.37 . The different mean was taken from the score of posttest minus the score of pretest. Based on the different mean, the mean score of experimental group is higher than the control group. It means that the treatment which given to the experimental group has an effect on students speaking ability.

The posttest score from both of the groups has been calculated by using t test in SPSS version 16. The p-value of posttest score of experimental and control group was 0.016 . The result of the calculation can be seen As follows. 
Based on the result, the p-value (sig. Language Teaching Method on the seventh 2-tailed) of posttest score from both of the grade students' speaking ability at SMPN 2 groups was 0.016. The p-value has been Yosowilangun Lumajang, Indonesia. compared with the significance level that used

The treatment was done by teaching

Table 2. Result of Group Statistic

\begin{tabular}{cccccc}
\hline & Posttest & $\mathrm{N}$ & Mean & $\begin{array}{c}\text { Std. Devia- } \\
\text { tion }\end{array}$ & $\begin{array}{c}\text { Std. Error } \\
\text { Mean }\end{array}$ \\
\hline \multirow{2}{*}{ Nilai } & Experiment & 22 & 75.23 & 3.927 & .837 \\
\cline { 2 - 6 } & Control & 22 & 71.82 & 5.011 & 1.068 \\
\hline
\end{tabular}

Table 3. Independent Sample t-test

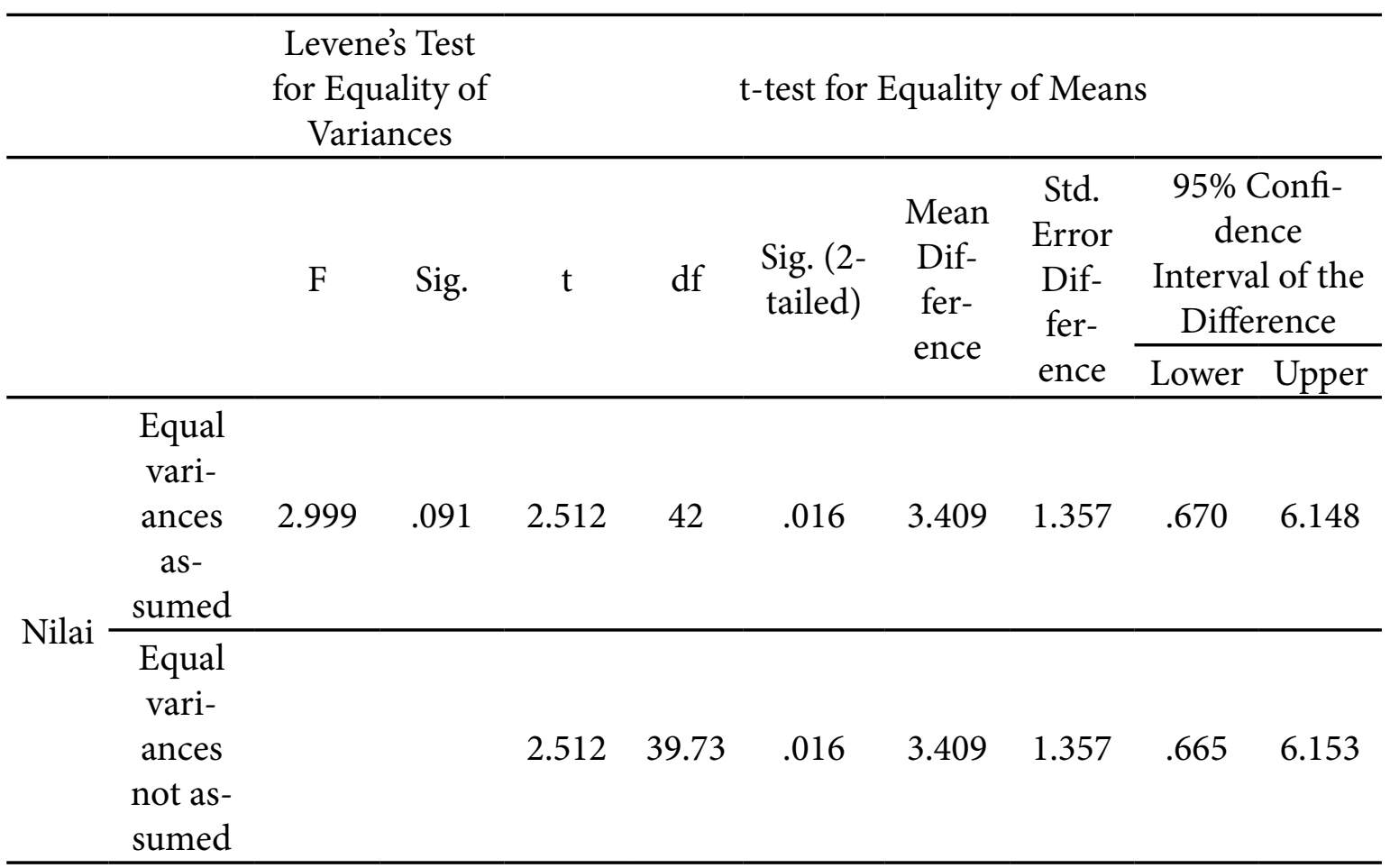

by the researcher. It may be said that the p-value of posttest is less than $5 \%$ or in other word, the $\mathrm{p}$-value $0.016<0.05$. From the explanation, it can be said that the null hypothesis (Ho) which stated that there was no significance effect of using Communicative Language Teaching Method on the seventh grade students' speaking ability at SMPN 2 Yosowilangun was rejected. In other word, the alternative hypothesis $(\mathrm{Ha})$ was accepted or "There is significance effect of using Communicative speaking to experimental group using Communicative Language Teaching Method and teaching speaking to control group using conventional method. After doing the research, the data is calculated by using SPSS version 16 and the result shows that experimental group had mean score 66.82 for pretest and 75.23 for posttest. The mean different is 8.41 . On the other hand, control group had mean score 70.23 for pretest and 71.82 for posttest. The mean different is 1.59 . The mean different is 
taken from the score of posttest minus the score of pretest. The mean score of experimental group is higher than the control group.

The result is the $\mathrm{p}$-value (sig. (2-tailed)) was 0.016 . The $\mathrm{p}$-value has been compare with the significance level that used by the researcher. The result was the p-value of posttest is less than $5 \%$ or in other word, the p-value $0.016<0.05$. From the explanation, the null hypothesis (Ho) which stated that there was no significance effect of using Communicative Language Teaching Method on the students' speaking ability was rejected. In other word, the alternative hypothesis ( $\mathrm{Ha})$ was accepted or "there was significance effect of using Communicative Language Teaching Method on the students' speaking ability."

Based on the explanation above, the experimental group shows high improvement of their speaking rather than the control group. This is because of the treatment concerned with the students' communication during the classroom activity. By knowing the topic given, the students are easier to find some ideas about what should they say, they enjoy the classroom activity and give them more desire to communicate with other using the target language. This statement is suitable with Applebaum's opinion (2007, p. 270). He stated that using CLT make the students enjoy using the target language in a meaningful way and showed more motivation in learning the target language. In the other hand, the mean of control group pretest and posttest is not showing much improvement. This condition is caused by the conventional method that they get, where this method still concerned with the English teacher. Make the teacher talk more than the students. This statement is suitable with Cottel \& Millis's opinion (in Dimitrios et. al. 2013, p. 76), she stated that the traditional (or conventional) teaching methods are teacher centered and include the use of lectures and discussions while the teaching materials and the student assessments are determined by the tutor and transmitted to students in various lectures. In the other hand, while doing the task; the students will be copied teacher explanation. For example, if the teacher gives them five examples of descriptive text, the students will only copied the five examples without trying to find other examples.

There is a weakness of the research, which is the students are difficult to follow the instruction. Because it was a new method for them, they need more guidance while doing their task and may cause anxiety for the researcher.

In general this research shows that CLT method can improvement of students' speaking ability. This statement is supported by $\mathrm{Wu}(2008$, p. 50), he stated that CLT emphasis the speaking skill in order to improve their communicative ability by focusing on meaning, and refuses error correction for maintaining the conversation. On other hand, Vongxey (2013, p. 50) stated that by using CLT, students seem to enjoy communication activities because they can engage in conversation pool to practice their English and improve the communication skills. So, it can be concluded that the students' speaking score is increasing after they are taught by using CLT.

\section{Conclusion}

Based on the result of data analysis, the null hypothesis (Ho) was rejected and the alternative hypothesis ( $\mathrm{Ha}$ ) was accepted. The conclusion is that "there is significant effect of using Communicative Language Teaching Method on students' speaking ability at SMPN 2 Yosowilangun Lumajang, Indonesia."

\section{References}

Applebaum, Bruce. (2007). Communicative Language Teaching: Theory, Practice, and Personal Experience. Mandiri, 9(4): 266-270.

Banciu, Victoria and Jireghie, Angela. 2012. Communicative Language Teaching. The Public Administration and Social Policies Review, 1(8): 94-98. 
Brown, H., Douglas. (2003). Language Assessment Principles and Classroom Practices. England: Longman.

Dimitrios, Belias et. al. 2013. Traditional Teaching Methods vs. Teaching Through The Application of Information and Communication Technologies in the Accounting Field: Quo Vadis? European Scientific Journal, 9(28): 73-101.

Hammer, Jeremy. (2002). The Practice of English Language Teaching. England.

Larsen, Diane and Freeman. (2000). Technique and Principles in Language Teaching. China: Oxford University Press.

Richard, C., Jack and Rodgers, S., Theodore. (2001). Approach and Methods in Language Teaching. United State of America: Cambridge University Press.

Safitri, R., Dina. The Effectiveness of Communicative Language Teaching in Speaking to the Eight Grade Students of SMPN 1 Semen Kediri in Academic Year 2014/2015. Kediri: Universitas Nusantara PGRI Kediri.

Shaftel, R., Fannie and Shaftel, George. (1982). Role Playing in the Curriculum. United State of America: Prentice-Hall, Inc., Englewood Cliffs, N. J.

Thornbury, Scott. (2005). How to Teach Speaking. Harlow, United Kingdom: Longman.

WU, Wen. (2008). Misunderstanding of Communicative Language Teaching. CCSE, 1(1): 50-53. 
